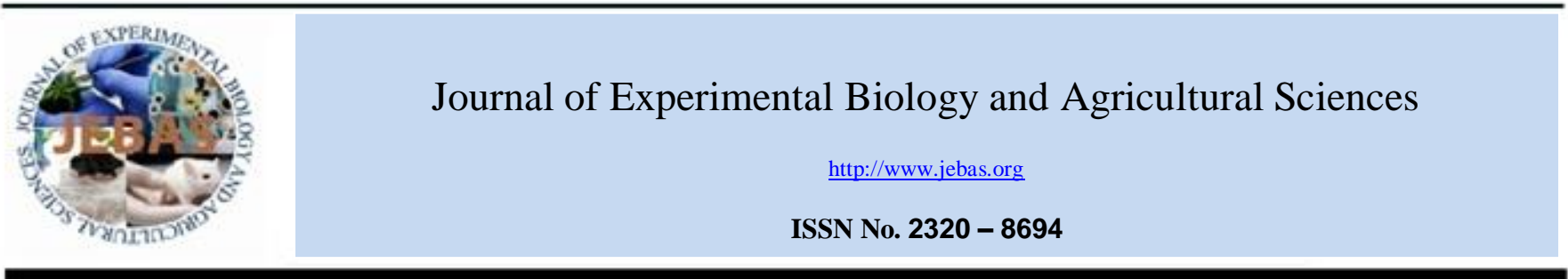

\title{
DOCUMENTATION OF PLANT DIVERSITY IN MARKETS OF GOALPARA DISTRICT OF ASSAM USED FOR FOOD AND GENERAL HEALTHCARE
}

\author{
Kaustav Kalyan Sharma ${ }^{1}$, Vivek Ghose ${ }^{1}$, Dipamoni Nath ${ }^{2}$, Dulal Chandra Boruah ${ }^{2}$, \\ Dharmeswar Barman ${ }^{2}$, Sheemanta Jyoti Deka ${ }^{1}$, Someswar Rao ${ }^{1,2 *}$
}

\footnotetext{
${ }^{1}$ Advanced level Institutional Biotech Hub, Department of Botany, Goalpara College, Goalpara, Assam, India.

${ }^{2}$ Department of Botany, Goalpara College, Goalpara, Assam, India
}

Received - March 27, 2019; Revision - May 26, 2019; Accepted - June 07, 2019

Available Online - June 10, 2019

DOI: http://dx.doi.org/10.18006/2019.7(3).316.328

KEYWORDS
Goalpara district
Weekly markets
Plants
Cultural beliefs
Nutrition

\begin{abstract}
Since the dawn of civilization public markets have played an important role in supplying goods for maintaining health and nutrition of mankind, especially in the rural areas. The present study was designed to document the local plants and plant products that are sold in different rural weekly markets of Goalpara district of Assam, India, which served particularly as food supplements or ingredients for local cuisine. This survey was conducted across a period of one year following a standard questionnaire, personal interviews with the sellers, documenting the plants sold, their parts used, mode of use and price range. Results showed that 71 number of plant species belonging to 41 families are being used as food and to treat various common ailments for maintaining overall health. Araceae and Rutaceae were found to be the most dominant plant families followed by Euphorbiaceae, Amaranthaceae, Apiaceae, Malvaceae, Rubiaceae and others as per the number of plant species is concerned The plant products constitute fruits, flowers, leaves, stems, tubers and rhizomes. The study gives an idea of the plant diversity of the area along with glimpses of the prevailing cultural beliefs and socio-economic condition of the locals.
\end{abstract}

* Corresponding author

E-mail: someswar.glp@yahoo.co.in ; bthubgoalparacollege@ gmail.com (Someswar Rao)

Peer review under responsibility of Journal of Experimental Biology and Agricultural Sciences.

Production and Hosting by Horizon Publisher India [HPI] (http://www.horizonpublisherindia.in/).

All rights reserved.
All the article published by Journal of Experimental Biology and Agricultural Sciences is licensed under a Creative Commons Attribution-NonCommercial 4.0 International License Based on a work at www.jebas.org.

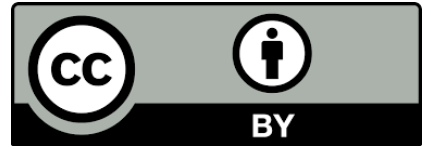




\section{Introduction}

Human dependence on plants for their basic requirements like food, medicine, clothes and shelter is as old as mankind itself and still in the modern age the majority of commercial products including pharmaceutical and healthcare, food and beverages, textiles, cosmetics and aromas are obtained from plants (Goyal et al., 2007; Khanuja, 2012; Gupta et al., 2018). All around the globe, traditional markets are considered as places for trade and marketing of plant and plant products, where cultures are expressed by means of regional trade, likewise markets acts as meeting spots where various ecologically and culturally diverse communities display and sell a diverse array of minerals, animals, plants and their derivatives. (Hooper et al., 1937; Linares \& Bye, 1987; Nicholson \& Arzeni, 1993; Martin, 1995; Cunningham, 2001; Parente \& da Rosa, 2001; Hanlidou et al., 2004; Williams et al., 2007a; Williams et al., 2007b; Williams et al., 2009; Giraldo et al., 2009; Silalahi et al., 2015; Tinitana et al., 2016; Tibuhwa, 2018). Indigenous people living on their traditional territory largely rely on plants and plant products sold in the public markets for general healthcare. This reliance can be attributed towards the cost-effective and easy accessible nature of the products. In general, the vendors in the market that sell plants for therapeutic and nutritional purposes acts as popular prescribers, conducting a practical exhibition and explanation of empirical knowledge about indications, preparation methods and use, plant parts and quantities used and other pertinent information (Santos et al., 2009; Silva \& Peixoto 2009; Leitao et al., 2009; De Carvalho et al., 2015).

Situated on the western part of Assam, Goalpara district shares its boundary with West and East Garo hills district of Meghalaya on the south, while the river Brahmaputra flows all along the north. Kamrup and Dhubri districts of Assam are located in the east and west respectively (Rabha, 2014). Semi evergreen and mixed deciduous are the main vegetation types of the area while some other subtypes also prevails. Taking account of the immense floristic diversity, Goalpara can be considered a rich district of Assam (Deka \& Nath, 2014).

Goalpara district is inhabited by many tribes and communities. Muslims community and tribes such as Rabha, Koch and Garo comprises the main population of the district while other tribes and communities like Bodo, Kalita and Hindu Bengalis are also among the residents (Deka \& Nath, 2014). The population of the district is 755133 in 2011 (Deka, 2016). It is quite common that different ethnic groups of the tribal dominated Goalpara district largely depends on plant and their derivatives for curing various health disorders. Herbaceous plants play a major role in disease cure and control while extracts derived from various parts of shrubs and trees are also deployed for treatment. The use of roots, stem, leaves, bark, seeds or even the whole plant is quite common. These plants are either collected from nearby forest areas or sometimes cultivated in the homesteads or home gardens. It is worth mentioning that different kinds of weeds growing in the agricultural fields as well as in the vicinity of the residences are also used for disease prevention and cure (Deka \& Nath, 2014). The dependence on plant and plant based products as sources of medicine and primary health supplements is still prevailing in these areas largely because of the prevailing traditional beliefs and ancestral cultures, easy access and cost effective nature of the products. In this aspect, the markets play a vital role as these are very well organized, generally established in the same day in every week and concentrate on collection, accumulation and selling of different products from far reaching areas in the same spot. The present study aims to investigate the diversity of edible plants and plant products sold in different local markets of Goalpara district, Assam and to understand their utilization by the locals as food and in prevention, treatment and healing of diseases as well as improvement of general healthcare.

\section{Material and Methods}

\subsection{Study area}

The geographical location of Goalpara district is between $25^{\circ}$ $53^{\prime} \mathrm{N}$ to $26^{\circ} 30^{\prime} \mathrm{N}$ latitude and $90^{\circ} 07^{\prime} \mathrm{E}$ to $91^{\circ} 05^{\prime} \mathrm{E}$ longitude (Rabha 2014). The area of Goalpara district is 1824 sq.km and the total forest area is 36915.27 hectares (Rabha, 2012). There are five revenue circles in the district viz., Lakhipur, Balijana, Rangjuli, Dudhnoi and Matia while Jaleswar, Lakhipur, Kharmuja, Balijana, Krishnai, Matia, Kushdhawa and Dudhnoi comprise the eight blocks of the district (Deka, 2016). The survey was conducted in different weekly markets of Goalpara district viz., Dhupdhara, Rangjuli, Darangiri, Dhanubhanga, Dhudhnoi, Krishnai, Tukura, Makri, Agia and Lakhipur over a period of 12 months in respective days of the weeks when the markets were held. Location map of the study area of Goalpara District of Assam, India is presented in Figure 1. 


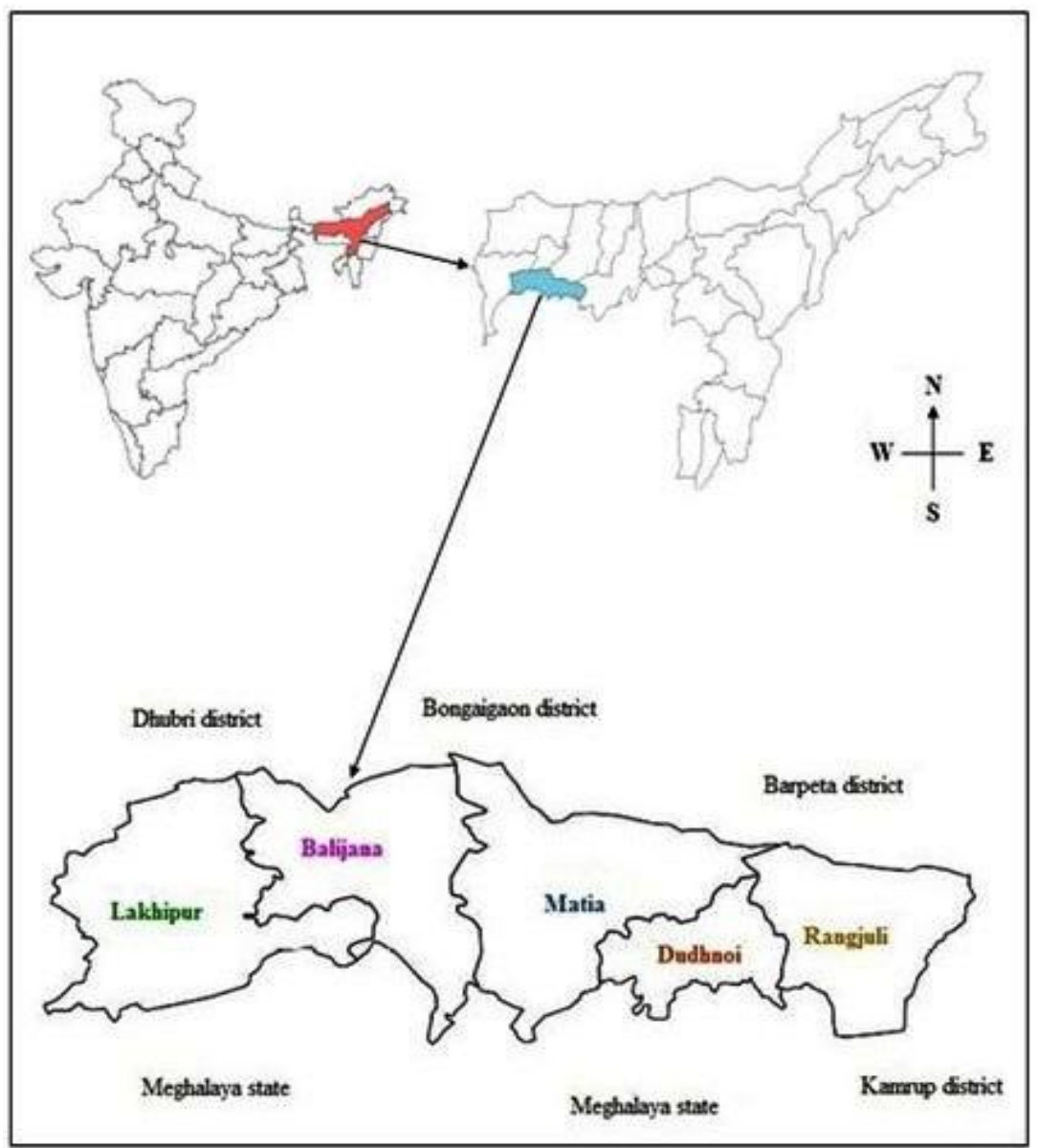

Figure 1: Location map of the study area of Goalpara District in Assam, India. (Map Source - Assam District Factbook 2018).

\subsection{Data Collection:}

Data collection was carried out by following a standard questionnaire which includes the local name, type of plant, plant part sold, mode of use, price range, place of origin of the plant, whether cultivated or collected from wild etc. The sellers were casually interviewed of their products and photographs were taken with due permission. Emphasis was given on selecting and documenting the plants that are not so commonly found. Later the collected documents were compared with standard literatures (Patiri \& Borah, 2007) to know their scientific names and other parameter such as family name, vernacular names, growth characteristics etc.

\section{Results}

The present study was conducted to document the diversity of agricultural and non agricultural plant and plant products sold at various local markets in Goalpara district of Assam. The results represented 71 plant species belonging to 41 Families which have been traditionally used by the locals for maintaining health and nutrition. In case of family, Araceae and Rutaceae were found to be the most dominant plant families followed by Euphorbiaceae, Amaranthaceae, Rubiaceae, Malvaceae and others as per the number of plant species per family is concerned. The plants include all forms of vegetation viz., herbs, shrubs, trees, climbers and aquatic vegetation (Figure 2). Different parts of the plants were in use (Figure 3). Table 1 represent the various plants sold in different markets of Goalpara district, Assam, along with their families, local Assamese names, growth habits, parts used, their uses and sold prices. The numbers of plant species belonging to different plant families are given in Figure 4. Figure 5 and Figure 6 shows the local products in different form available at different markets from Goalpara District. 
Table 1: Plants sold in markets of Goalpara district, Assam with their family, local names, growth habit, parts used/ uses and price.

\begin{tabular}{|c|c|c|c|c|}
\hline Botanical name with Family & $\begin{array}{l}\text { Local Name/ } \\
\text { Vernacular } \\
\text { name }\end{array}$ & $\begin{array}{l}\text { Growth } \\
\text { habit }\end{array}$ & Parts used/Uses & Price \\
\hline Aegle marmelos (L.) Correa. (Rutaceae) & Bel & $\mathrm{T}$ & Fruits are used to prepare juice. & Rs.5/piece. \\
\hline Alocasia acuminata Schott. (Araceae) & Kochu & $\mathrm{H}$ & Tubers are used as vegetables. & Rs. $30-40 / \mathrm{kg}$. \\
\hline Alocasia cucullata (Lour.) Schott. (Araceae) & Boga kochu & $\mathrm{H}$ & $\begin{array}{l}\text { Leaves, stem and tubers are eaten, } \\
\text { leaves used as to cure external body } \\
\text { pain. }\end{array}$ & Rs.5/bundle. \\
\hline Alocasia indica (Lour.) Koch. (Araceae) & Man Kochu & $\mathrm{H}$ & Tubers/roots are used as vegetables. & Rs.30-40/kg. \\
\hline Alocasia odora (Lindl.) K.Koch. (Araceae) & Dudh Kochu & $\mathrm{H}$ & Petioles are used as vegetables. & Rs.5/bundle. \\
\hline Amaranthus virdis L. (Amaranthaceae) & Khutura sak & $\mathrm{H}$ & Leaves are used as vegetables. & Rs.10/3-4 bundles. \\
\hline Amaranthus spinosus L. (Amaranthaceae) & Katakhutura & $\mathrm{H}$ & Leaves are used as vegetables & Rs.10/3-4 bundles. \\
\hline Amaranthus tricolor L. (Amaranthaceae) & Datha & $\mathrm{H}$ & Leaves are used as vegetables & Rs.10/ $4-5$ bundles. \\
\hline Artocarpus heterophyllus Lamk. (Moraceae) & Kothal & $\mathrm{T}$ & Fruits are eaten raw. & Rs/piece (price vary on size). \\
\hline Averrhoa carambola L. (Oxalidaceae) & Kordoi & $\mathrm{T}$ & $\begin{array}{l}\text { Fruits are eaten raw also used to } \\
\text { make curry. }\end{array}$ & Rs. 20-30/kg. \\
\hline Azadiracta indica A. Juss. (Meliaceae) & Maha-neem & $\mathrm{T}$ & $\begin{array}{l}\text { Leaves are eaten for bitter taste, used } \\
\text { to treat fever, worm infection and } \\
\text { skin diseases. }\end{array}$ & Rs. 5/bundle. \\
\hline Baccaurea ramiflora Lour. (Euphorbiaceae) & Leteku & $\mathrm{T}$ & Fruits are eaten raw. & Rs. 10/bundle. \\
\hline Bacopa monneri (L.) Pennell (Scorphulariaceae) & Brahmi sak & $\mathrm{H}$ & Leaves are used as vegetables & Rs. 5/bundle. \\
\hline Basella alba L. var. rubra (L.) Stewart. (Basellaceae) & $\begin{array}{l}\text { Ronga Puroi/Pui } \\
\text { xak }\end{array}$ & $\mathrm{C}$ & Leaves are used as vegetables & Rs. 5/bundle. \\
\hline Basella alba L. var. alba (Basellaceae) & Boga Puroi sak & $\mathrm{C}$ & Leaves are used as vegetables & Rs. 5/bundle. \\
\hline Brassica nigra (L.) W.D.J. Koch. (Brassicaceae) & Soriyoh Sak & $\mathrm{H}$ & Leaves are used as vegetables & Rs.10/ $4-5$ bundles. \\
\hline Canavalia cathartica Thouars (Fabaceae) & Kamtal urahi & $\bar{C}$ & Fruits used as vegetables. & Rs. 50/kg. \\
\hline Capsicum chinense Jacq. (Solanaceae) & Bhot Jolokia & $\mathrm{S}$ & Fruits are eaten raw. & Rs. $10 / 3-4$ pieces. \\
\hline Carica papaya L. (Caricaceae) & Amita & $\mathrm{T}$ & $\begin{array}{l}\text { Ripe fruits are eaten raw. Unripe } \\
\text { fruits are used to treat stomach } \\
\text { problems. Flowers used to treat fever. }\end{array}$ & $\begin{array}{l}\text { Rs. } 40 / \mathrm{kg} \text { (ripe fruit) } \\
\text { Rs. } 15-20 / \mathrm{Kg} \text { (raw fruit) } \\
\text { Rs. 10/part (flowers) } \\
\end{array}$ \\
\hline Centella asiatica (L.) Urban (Apiaceae) & Bor manimuni & $\mathrm{H}$ & $\begin{array}{l}\text { Leaves are used to treat stomach } \\
\text { troubles. }\end{array}$ & Rs.5/ part. \\
\hline Chenopodium album L. (Chenopodiaceae) & Bhatua/Jilmil & $\mathrm{H}$ & Leaves are used as vegetables & Rs.10/4-5 bundles. \\
\hline $\begin{array}{l}\text { Cinnamomum tamala (Buch.-Ham.) Nees \& } \\
\text { Eberm. (Lauraceae) }\end{array}$ & Tejpat & $\mathrm{T}$ & Leaves are used as flavouring agent. & Rs.5/bundle. \\
\hline Citrus grandis (L.) Osbeck (Rutaceae) & Robab tenga & $\mathrm{T}$ & Fruits are eaten raw. & Rs.10/piece. \\
\hline Citrus medica L. (Rutaceae) & Jora nemu & $\mathrm{S}$ & $\begin{array}{l}\text { Fruits are eaten raw considered as a } \\
\text { source of Vitamin } \quad \text { C and } \\
\text { antioxidants. }\end{array}$ & Rs.10/2pieces. \\
\hline Colocasia esculenta (L.) Schott (Araceae) & Kola kochu & $\mathrm{H}$ & $\begin{array}{l}\text { Tubers are used as vegetables. } \\
\text { Leaves are used to treat joint pains. }\end{array}$ & Rs.5/ bundle. \\
\hline Corchorus capsularis L. (Malvaceae) & Moraphat & $S$ & $\begin{array}{l}\text { Tender leaves are eaten as } \\
\text { vegetables. }\end{array}$ & Rs. $10 / 3-4$ bundles. \\
\hline
\end{tabular}




\begin{tabular}{|c|c|c|c|c|}
\hline Botanical name with Family & $\begin{array}{l}\text { Local Name/ } \\
\text { Vernacular } \\
\text { name }\end{array}$ & $\begin{array}{l}\text { Growth } \\
\text { habit }\end{array}$ & Parts used/ Uses & Price \\
\hline Curcuma longa $\mathrm{L}$. (Zingiberaceae) & Halodhi & $\mathrm{H}$ & $\begin{array}{l}\text { Rhizomes are used as spice, against } \\
\text { arthritis. Paste of rhizomes applied } \\
\text { topically over small burns. }\end{array}$ & $\begin{array}{l}\text { Rs. 60/kg (raw) } \\
\text { Rs. } 250 / \mathrm{kg} \text { (powder) }\end{array}$ \\
\hline Dillenia indica L. (Dilleniaceae) & Ou tenga & $\mathrm{T}$ & $\begin{array}{l}\text { Fruits are eaten raw or used in pickles } \\
\text { and to prepare curry. Fruit decoction } \\
\text { used to treat hair fall. Used to prepare } \\
\text { fish curry. }\end{array}$ & Rs.5/piece. \\
\hline Dioscorea alata L. (Dioscoreaceae) & Kath alu & $\mathrm{C}$ & $\begin{array}{l}\text { Tubers are used as vegetables. Used } \\
\text { to treat indigestion. }\end{array}$ & Rs. 40-50/kg. \\
\hline Dioscorea bulbifera L. (Dioscoreaceae) & Gosh Alu & $\mathrm{C}$ & Tubers are used as vegetables. & Rs. $30-40 / \mathrm{kg}$. \\
\hline $\begin{array}{l}\text { Diplezium esculentum (Retz.) Sw. } \\
\text { Woodsiaceae (Athyriaceae) }\end{array}$ & Dhekia sak & $\mathrm{H}$ & $\begin{array}{l}\text { Leaves and tender stem used as } \\
\text { seasonal vegetables. }\end{array}$ & Rs. 10/ bundle. \\
\hline Elaeocarpus floribundus Bl. (Elaeocarpaceae) & Jolphai & $\mathrm{T}$ & Fruits are used in pickles, eaten raw & Rs. $25-30 / \mathrm{kg}$. \\
\hline Enhydra fluctuans Lour. (Asteraceae) & Helochi & $\mathrm{H}$ & $\begin{array}{l}\text { Leaves and tender shoots are used to } \\
\text { prepare curry in local cuisine. }\end{array}$ & Rs. 10/2-3bundles. \\
\hline Eryngium foetidum L. (Apiaceae) & Man dhania & $\mathrm{H}$ & $\begin{array}{l}\text { Leaves are used as garnishing and } \\
\text { flavouring agent. }\end{array}$ & Rs. 10/ bundle. \\
\hline Euryle ferox Salisb. (Nymphaeaceae) & Makhana & AV & Fruits are eaten raw. & Rs. 4-5/piece. \\
\hline Flacourtia jangomas (Lour.) Raeusch (Salicaceae) & Ponial & $\mathrm{T}$ & Fruits are eaten raw. & Rs. 40/kg. \\
\hline Garcinia pedunculata Roxb. (Clusiaceae) & Bor thekera & $\mathrm{T}$ & $\begin{array}{l}\text { Fruits are eaten raw. Dried fruit rinds } \\
\text { used to cure dysentery and diarrhea. } \\
\text { Also used to prepare fish curry. }\end{array}$ & $\begin{array}{l}\text { Rs. 5/piece (raw) } \\
\text { Rs. 200/Kg (dried rinds). }\end{array}$ \\
\hline Hibiscus subdarifa L. (Malvaceae) & Mesta tenga & $\mathrm{H}$ & $\begin{array}{l}\text { Leaves are used to prepare curry with } \\
\text { lentils. Fruits are used to prepare jam } \\
\text { and jelly. }\end{array}$ & $\begin{array}{l}\text { Rs.10/bundle (leaves). } \\
\text { Rs.10/part (fruits) }\end{array}$ \\
\hline Houttuynia cordata Thunb. (Saururaceae) & Masundari & $\mathrm{H}$ & $\begin{array}{l}\text { Leaves are used as vegetables and } \\
\text { used against diarrhea. }\end{array}$ & Rs.10/bundle. \\
\hline Hydrocotyle sibthorpioides Lamk. (Apiaceae) & Xaru manimuni & $\mathrm{H}$ & $\begin{array}{l}\text { Leaves paste is used to enhance } \\
\text { appetite after disease. }\end{array}$ & Rs. 10/3-5bundles. \\
\hline Hedyotis corymbosa (L.) Lam. (Rubiaceae) & Bon jaluk & $\mathrm{H}$ & Leaves are used as vegetables. & Rs.5/bundle. \\
\hline Ipomoea aquatica Forsk. (Convolvulaceae) & Kolmou & AV & $\begin{array}{l}\text { Leaves are used to prepare curry in } \\
\text { local cuisine, decoction of leaves used } \\
\text { against liver problems. }\end{array}$ & Rs.5/2bundles. \\
\hline Ipomoea batatas (L.) Lamk. (Convolvulaceae) & Mitha Alu & $\mathrm{C}$ & $\begin{array}{l}\text { Tubers are eaten raw or as vegetables } \\
\text { in local cuisine. }\end{array}$ & Rs. 30-40/kg. \\
\hline Leucas plukenetii (Roth.) Spreng. (Lamiaceae) & Dron/Doron xak & $\mathrm{H}$ & $\begin{array}{l}\text { Leaves are bitter in taste used against } \\
\text { jaundice, and also in local cuisine. }\end{array}$ & Rs.5/bundle. \\
\hline Malva verticillata $\mathrm{L}$. (Malvaceae) & Lofa sak & $\mathrm{H}$ & $\begin{array}{l}\text { Leaves are used as vegetables in local } \\
\text { cuisine. }\end{array}$ & Rs. 10/3-4bundles. \\
\hline Manihot esculenta Crantz. (Euphorbiaceae) & Simalu alu & $\mathrm{S}$ & $\begin{array}{l}\text { Roots are used as vegetables. Used to } \\
\text { treat stomach problems. }\end{array}$ & $\begin{array}{l}\text { Rs. } 40-60 / \mathrm{kg} . \\
\text { Rs. } 20-30 / \text { bundle. }\end{array}$ \\
\hline Mentha virdis L. (Lamiaceae) & Pudina & $\mathrm{H}$ & $\begin{array}{l}\text { Leaves are used as appetite enhancers } \\
\text { and as flavouring and garnishing } \\
\text { agent. }\end{array}$ & Rs. 10/3-5bundles. \\
\hline Meyna spinosa Roxb. ex. Link. (Rubiaceae) & Moinphal & $\mathrm{T}$ & $\begin{array}{l}\text { Fruits are used as vegetables. Dried } \\
\text { fruits are soaked in water and used } \\
\text { against dysentery. }\end{array}$ & Rs.10/part (9-10 fruits per part) \\
\hline Moringa oleifera Lamk. (Moringaceae) & Sajina & $\mathrm{T}$ & $\begin{array}{l}\text { Fruits and leaves are used as } \\
\text { vegetables, leaves decoction is used } \\
\text { to treat fever and diabetes. }\end{array}$ & $\begin{array}{l}\text { Rs. 200/kg. (tender drumsticks). } \\
\text { Rs.60/kg. (mature drumsticks). }\end{array}$ \\
\hline
\end{tabular}




\begin{tabular}{|c|c|c|c|c|}
\hline Botanical name with Family & $\begin{array}{l}\text { Local Name/ } \\
\text { Vernacular } \\
\text { name }\end{array}$ & $\begin{array}{l}\text { Growth } \\
\text { habit }\end{array}$ & Parts used/Uses & Price \\
\hline Murrya koenigii (L.) Spreng. (Rutaceae) & Narasingha & S & $\begin{array}{l}\text { Leaves are used as flavouring agent } \\
\text { and appetizer. }\end{array}$ & Rs. 10/3-4bundles. \\
\hline Musa balbisiana Colla. (Musaceae) & $\begin{array}{l}\text { Athia kol/Bhim } \\
\text { kol }\end{array}$ & $\mathrm{H}$ & $\begin{array}{l}\text { Fruits are eaten raw, stem and flower } \\
\text { as vegetables. }\end{array}$ & Rs. 40-50/ dozen. \\
\hline Nyctanthes arbor-tristis L. (Oleaceae) & Sewali phul & $\mathrm{T}$ & Flowers are used to enhance appetite. & Rs.5/part. \\
\hline Nymphaea rubra Roxb.ex Andrews (Nymphaeaceae) & Seluk & AV & Roots are used as vegetables. & Rs. $40-50 / \mathrm{kg}$. \\
\hline Paederia foetida L. (Rubiaceae) & Bhedailota & $\mathrm{C}$ & $\begin{array}{l}\text { Leaves decoction is used to cure } \\
\text { stomach ache, prepared with fish to } \\
\text { enhance appetite. }\end{array}$ & Rs. 10/2-3bundles. \\
\hline Phlogocanthus thyrsiflorus (Roxb.) Nees (Acanthaceae) & Ronga bahka tita & S & $\begin{array}{l}\text { Flowers are dried and used to treat } \\
\text { jaundice and fever. }\end{array}$ & Rs.20/part. \\
\hline Phyllanthus acidus (L.) Skeels (Euphorbiaceae) & Holfoli & $\mathrm{T}$ & Fruits are acidic in taste eaten raw. & Rs.5 /part. \\
\hline Phyllanthus emblica L. (Euphorbiaceae) & Amlokhi & $\mathrm{T}$ & $\begin{array}{l}\text { Fruits are considered as source of } \\
\text { Vitamin C, consumed for general } \\
\text { health improvements. }\end{array}$ & Rs. 30-40/kg. \\
\hline Piper betle L. (Piperaceae) & Pan & $\mathrm{C}$ & $\begin{array}{l}\text { Leaves are used as mouth freshener } \\
\text { after meal. Paste of leaves used to } \\
\text { treat anal fissure. }\end{array}$ & Rs. 10/Bundle \\
\hline Pipernigrum L. (Piperaceae) & $\begin{array}{l}\text { Jaluk/Gol } \\
\text { morich }\end{array}$ & $\mathrm{C}$ & $\begin{array}{l}\text { Fruits are used as spice made paste } \\
\text { with honey to cure cough and sore } \\
\text { throat. }\end{array}$ & $\begin{array}{l}\text { Rs.20/part (young peppercorns). } \\
\begin{array}{l}\text { Rs.90/100gms } \\
\text { peppercorns). }\end{array}\end{array}$ \\
\hline Polygonum chinense L. (Polygonaceae) & Madhusuleng & $\mathrm{H}$ & Leaves are used to treat dysentery. & Rs.5/bundle. \\
\hline Solanum indicum L. (Solanaceae) & Tit bhekuri & S & $\begin{array}{l}\text { Fruits are used as vegetables with } \\
\text { rice. }\end{array}$ & Rs.10/part (25-30 fruits per part) \\
\hline Spilanthes paniculata Wall. ex D.C. (Asteraceae) & Huhuni sak & $\mathrm{H}$ & $\begin{array}{l}\text { Leaves are used to treat wound } \\
\text { healing. }\end{array}$ & Rs.5/bundle. \\
\hline Spondias pinnata (L.f.) Kurz. (Anacardiaceae) & Amora & $\mathrm{T}$ & $\begin{array}{l}\text { Fruits are eaten raw, prepared curry } \\
\text { with fish. }\end{array}$ & Rs 20-30/kg. \\
\hline $\begin{array}{l}\text { Swertia chirayita (Roxb. ex. Flem.) Karsten } \\
\text { (Gentianaceae) }\end{array}$ & Chirota tita & $\mathrm{H}$ & $\begin{array}{l}\text { Dried leaves are used against fever, } \\
\text { stomach problems. }\end{array}$ & Rs.5/dried bundle. \\
\hline Tamarindus indica L. (Fabaceae) & Teteli & $\mathrm{T}$ & $\begin{array}{l}\text { Fruits are eaten raw or in curry and } \\
\text { pickles for sour flavor. }\end{array}$ & $\begin{array}{l}\text { Rs.40-60 /kg. (dried) } \\
\text { Rs. 10/part (raw fruits). }\end{array}$ \\
\hline Terminalia chebula Retz. (Combretaceae) & Silikha & $\mathrm{T}$ & $\begin{array}{l}\text { Dried fruits are used as mouth } \\
\text { fresheners, }\end{array}$ & Rs. 10/part. \\
\hline Terminalia bellerica (Gaertn.) Roxb. (Combretaceae) & Bhomora & $\mathrm{T}$ & $\begin{array}{l}\text { Fruits are used to cure gastritis, } \\
\text { blotting and constipation. }\end{array}$ & Rs.40-50/kg. \\
\hline $\begin{array}{l}\text { Trapa natans L. var. bispinosa (Roxb.) Makino } \\
\text { (Trapaceae) }\end{array}$ & $\begin{array}{l}\text { Singori/Pani } \\
\text { phal }\end{array}$ & AV & Fruits are eaten raw. & Rs. $50-60 / \mathrm{kg}$. \\
\hline Zanthoxylum oxyphyllum Edgw. (Rutaceae) & Mezenga & S & Young leaves are used as vegetables. & Rs. 10/1-2bundles. \\
\hline Zingiber officinallis Rosc. (Zingiberaceae) & Ada & $\mathrm{H}$ & $\begin{array}{l}\text { Rhizomes are used as spice } \\
\text { condiments, used to treat minor } \\
\text { stomach problems. Dried rhizomes } \\
\text { are used as mouth fresheners and } \\
\text { digestive agents. }\end{array}$ & Rs.80-100/kg. \\
\hline Zizyphus mauritiana Lamk. (Rhamnaceae) & Bogori & $\mathrm{T}$ & $\begin{array}{l}\text { Fruits are eaten raw, or used in } \\
\text { pickles. Used to treat diabetes. }\end{array}$ & Rs. $30-40 / k g$. \\
\hline
\end{tabular}

T- tree; S- shrub; H- herb; C- climber; AV- aquatic vegetation 


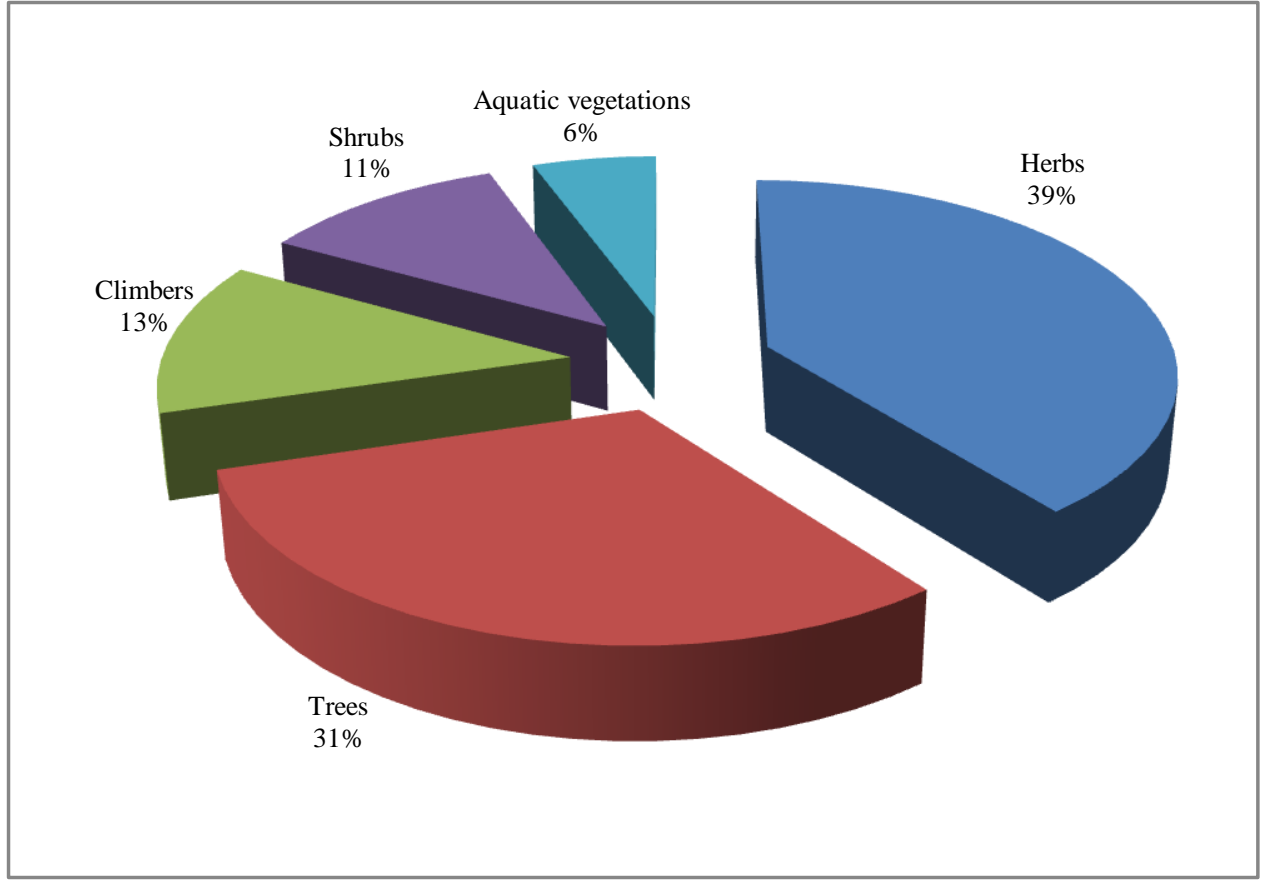

Figure 2 Plant growth habits.

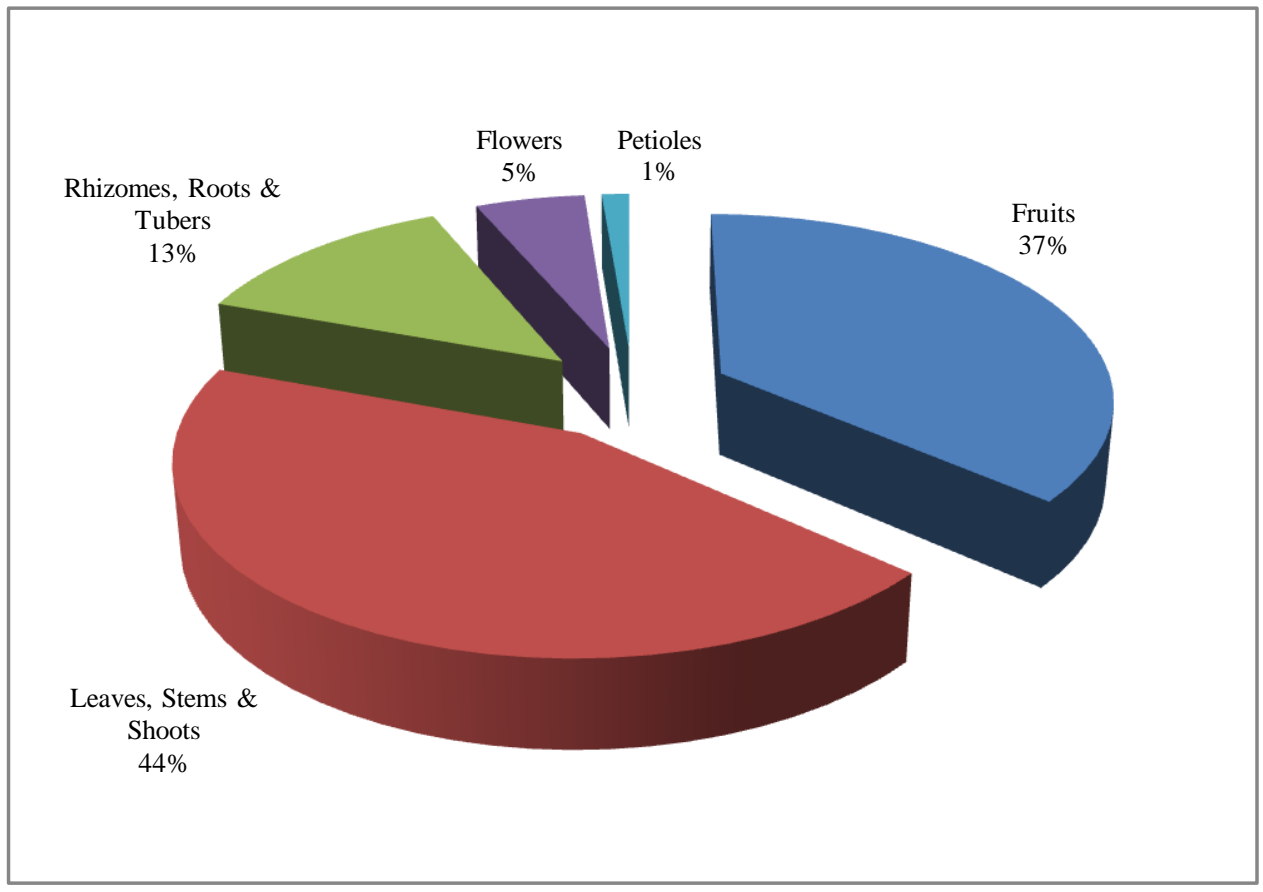

Figure 3 Plant parts used

Journal of Experimental Biology and Agricultural Sciences http://www.jebas.org 


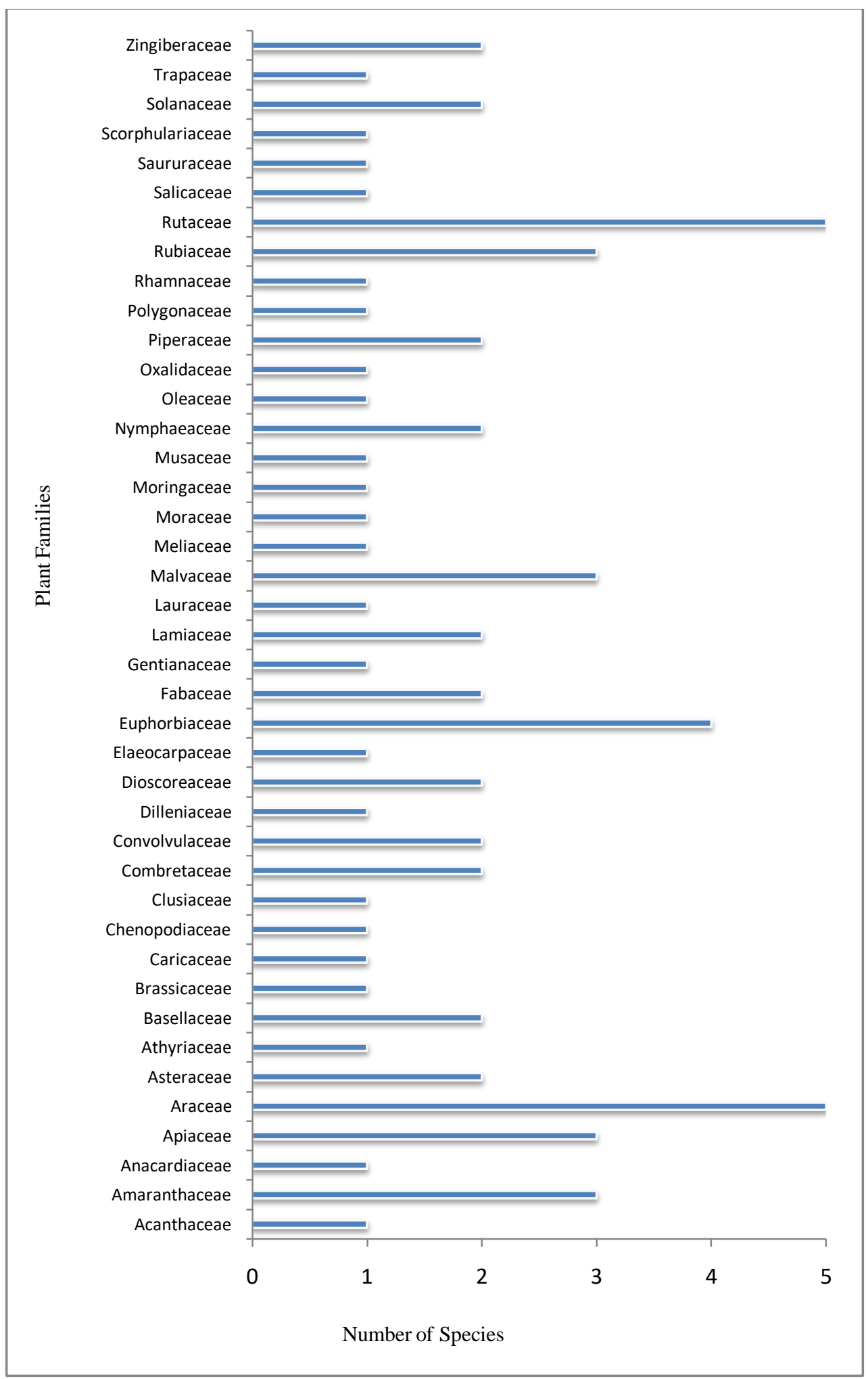

Figure 4 Number of indivials from each plant families recorded in the survey. 

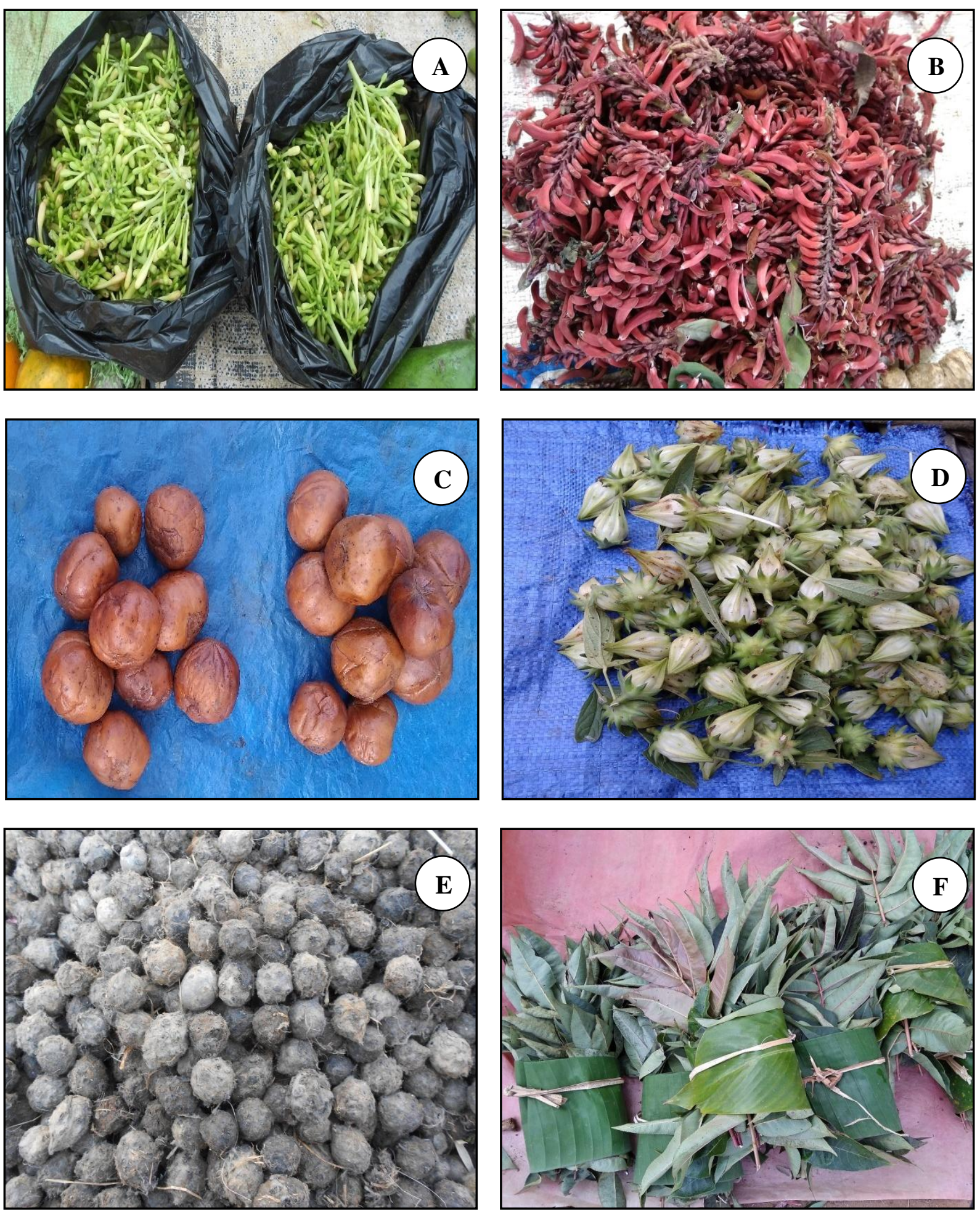

Figure 5 Local products sold at different markets. A- Flowers of Caraya papaya. B- Flowers of Phlogocanthus thyrsiflorus. C- Fruits of Meyna spinosa. D- Fruits of Hibiscus subdarifa. E- Tubers of Nymphaea rubra. F- Leaves of Zanthoxylum oxyphyllum.

Journal of Experimental Biology and Agricultural Sciences http://www.jebas.org 

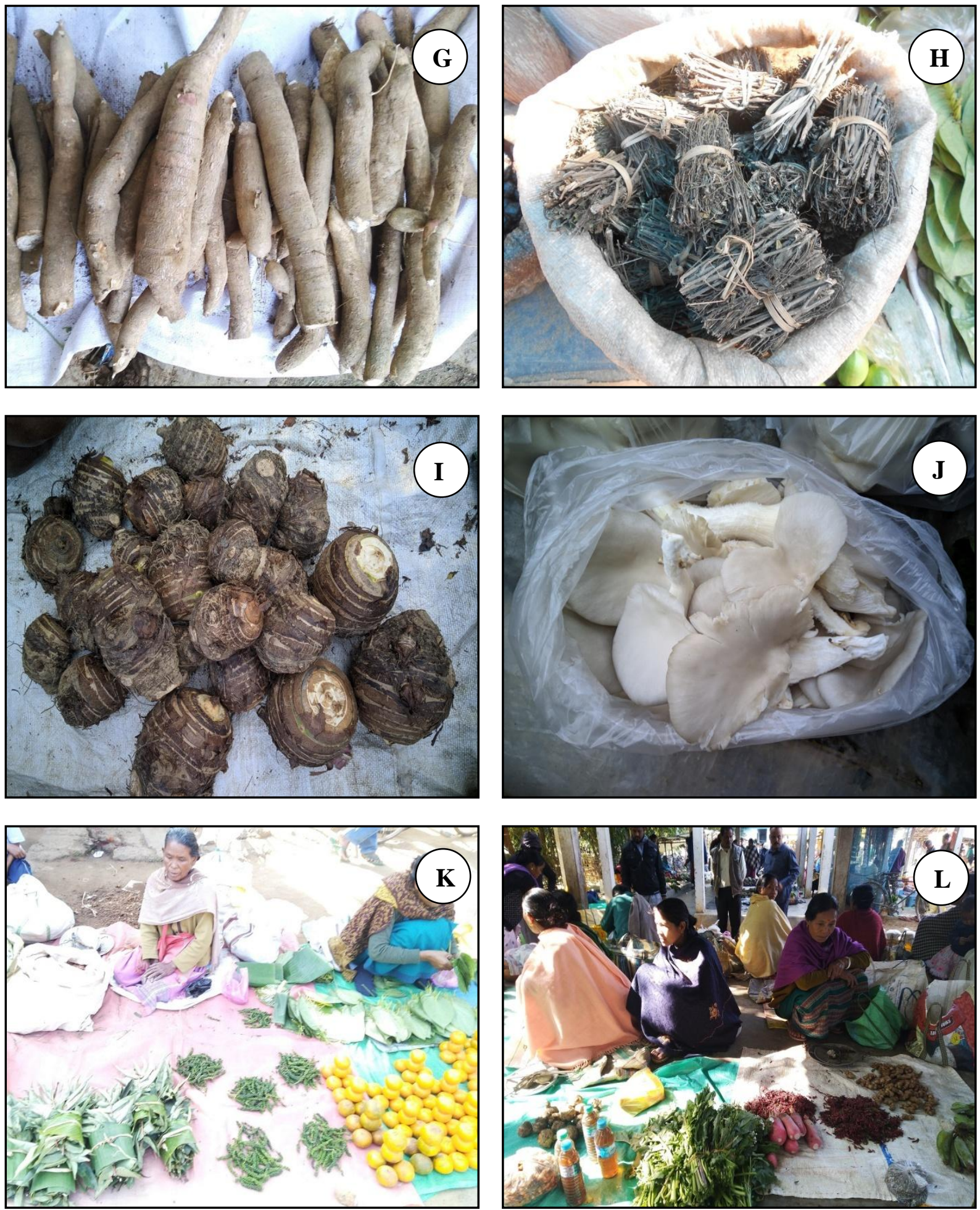

Figure 6 Local products sold at different markets. G- Roots of Manihot esculenta. H- Dried Swertia chirayita. I- Tubers of Colocasia esculenta. J- Local Mushroom. K and L- Women vendors at different markets.

Journal of Experimental Biology and Agricultural Sciences http://www.jebas.org 


\section{Discussion}

Rural markets represent one of the main supplementary incomes for local people that are particularly utilized at household level. Moreover, sellers along with their own goods also sell purchased products in order to meet the demands of the local people (Vlkova et al., 2015). The sellers in the weekly markets of Goalpara district constitute men and women of all age groups but it was observed that the majority of traders were women aged between of $30-70$ years. This observation is in support of some earlier investigations that reported that the women constitute the major part of the traders of medicinal plant materials (Idu et al., 2010; Vlkova et al., 2015).

The major plant products traded in the area were derived from plants of all growth habits but trees and herbs were predominant sources. The collected plants were found to be very common among the people and were used in traditional healthcares for a variety of disease conditions such as fever, jaundice and other liver problems, skin diseases, joint pain, small burns, hair fall, indigestion, dysentery, diarrhea, diabetes, constipation, cold and cough etc. and general health improvements (personal communications, table 1). The leafy vegetables, fruits and tubers also form an integral part of the regular local cuisine for the people of Goalpara district and many are used as appetite enhancers. The rates of the sold items varied from market to market, season to season depending on the quality and abundance. Occasionally locally grown mushrooms are also sold in the markets.

A number of studies have been carried out on the trade of medicinal and wild edible plant from across the globe. Dogan et al. (2013) reported, a total of 46 wild edible plants sold in the local markets of Izmir, Turkey that play an important role in their diet. Plants used were either eaten raw, cooked by boiling in water, frying in oil or baked to be served as dishes such as stew, salad as hot drink. As per Dogan \& Nedelcheva (2015), in the open air markets at both sides of the Bulgarian-Turkish border a total of 41 wild plants belonging to 20 families are sold, among which approximately $17 \%$ of the plants were common and widely reported. Kasper-Pakosz et al. (2016) recorded 468 species of plants and 32 species of mushrooms sold in the open-air markets of southeastern Poland. Likewise, Khruomo \& Deb (2018) documented a total of 47 indigenous wild edible fruits belonging to 29 family and 39 genera from Nagaland, India. In another study Łuczaj et al. (2013) stated that in every market in Dalmatia (southern Croatia), wild edible plant are sold as plant mixes, usually composed of just a few species of wild as well as cultivated vegetables to a lesser extent. In the present study many plants and plant products are documented that are rarely found in the regular day to day markets which give an idea about the species richness of these open air weekly markets of Goalpara district of Assam. A surprising fact about these open air markets is their ability to attract customers from distant places by virtue of this abundance and unique species composition. These much awaited open air markets act as support system for the sellers to generate financial assistance from the home grown or collected products as for some it is the sole source of income and livelihood. On the other hand the consumers gain advantage from the fresh and nutritive natural products sold at these markets.

\section{Conclusion}

The study documented the current plant diversity of the various markets of Goalpara district of Assam, India. As many as 71 plant species being recorded, sold in the local weekly markets which fetch good income to rural communities. The edible species also form a good source of nutrients in local diets besides improving the overall health. The study reflects the high dependence on these resources by the tribal and non tribal communities of Goalpara district. Furthermore it throws some light in identifying the fundamental plants which are being sold in these local markets, their availability, price range with their common uses. These types of studies may be helpful in identifying rare and endemic plant species for their conservation and sustainable use.

\section{Acknowledgement}

The authors are highly grateful to the Department of Biotechnology, Govt. of India for the financial assistance. We deeply acknowledge the co-operation received from the local people interviewed during out the survey.

\section{Conflict of Interest}

No conflict of interest.

\section{References}

Assam District Factbook (2018) Goalpara District. (Key Socioeconomic Data of Goalpara District, Assam) January, 2018. http://www.datanetindiaebooks.com/District_Factbook/Assam/Go alpara. pdf, accessed on 16 February 2019 .

Cunningham AB (2001) Applied Ethnobotany: People Wild Plant Use and Conservation. People and Plants Conservation. London: Earthscan Publications.

De Carvalho Nilo Bitu V, de Carvalho Nilo Bitu V, Matias EF, de Lima WP, da Costa Portelo A, Coutinho HD, de Menezes IR . (2015) Ethnopharmacological study of plants sold for therapeutic purposes in public markets in Northeast Brazil. Journal of Ethnopharmacology 172: 265-272. 
Deka K, Nath N (2014) Indigenous Medicinal Plant Knowledge of Cough or Bronchial Problems in Goalpara District (N.E. India). International Journal of Pure and Applied Bioscience 2: 80-87.

Deka P (2016) A Study on Disparity of Literacy Pattern between Scheduled Castes and Scheduled Tribe Population of Goalpara District, Assam. International Journal of Current Research 8: 30854-30856.

Dogan Y, Nedelcheva A (2015) Wild plants from open markets on both sides of the Bulgarian - Turkish border. Indian Journal of Traditional Knowledge 14: 351-358.

Dogan Y, Ugulu I, Durkan N (2013) Wild edible plants sold In the local markets of Izmir, Turkey. Pakistan Journal of Botany 45: 177-184.

Giraldo D, Baquero E, Bermúdez A, Oliveira-Miranda MA (2009) Medicinal plant trade characterization in popular markets of Caracas. Acta Botanica Venezuelica 32: 267-301.

Goyal BR, Agrawal BB, Goyal RK, Mehta AA (2007) Phytopharmacology of Moringa oleifera Lam.: An overview. Natural Product Radiance 6: 347-353.

Gupta S, Jain R, Kachhwaha S, Kothari SL (2018) Nutritional and medicinal applications of Moringa oleifera Lam.-Review of current status and future possibilities. Journal of Herbal Medicine 11: 1-11.

Hanlidou E, Karousou R, Kleftoyanni V, Kokkini S (2004) The herbal market of Thessaloniki ( $\mathrm{N}$ Greece) and its relation to the ethnobotanical tradition. . Journal of Ethnopharmacology 91: 281-99.

Hooper D, Field H, Dahlgren BE (1937) Useful Plants and Drugs of Iran and Iraq. Volume 9. Chicago: 7 Field Museum of Natural History.

Idu McD, Erhabor JO, Efijuemue HM (2010) Documentation on medicinal plants sold in markets in Abeokuta, Nigeria. Tropical Journal of Pharmaceutical Research 9: 110-118.

Kasper-Pakosz R, Pietras M, Łuczaj L (2016) Wild and native plants and mushrooms sold in the open-air markets of southeastern Poland. Journal of Ethnobiology and Ethnomedicine 12: 1-17.

Khanuja SPS (2012) Functional diversity of plant metabolome and microbiome in health services to the human life. Proceedings of the National Academy of Sciences, India Section B: Biological Sciences. 82: 291-294.

Khruomo N, Deb CR (2018) Indigenous wild edible fruits: sustainable resources for food, medicine and income generation a study from Nagaland, India. Journal of Experimental Biology and Agricultural Sciences 6: $405-413$.
Leitao F, Fonseca-Kruel VS, Silva IM, Reinert F (2009) Urban ethnobotany in Petropolis and Nova Friburgo (Rio de Janeiro, Brazil). Revista Brasileira de Farmacognosia 19: 333-342.

Linares E, Bye RA (1987) A study of four medicinal plant complexes of Mexico and adjacent United States. Journal of Ethnopharmacology 19:153-83.

Luczaj L, Zovko Končić M, Miličević T, Dolina K, Pandža M (2013) Wild vegetable mixes sold in the markets of Dalmatia (southern Croatia). Journal of Ethnobiology and Ethnomedicine 9: 1-12.

Martin GJ (1995) Ethnobotany A Methods Manual. vol. 1. London: Earthscan Publications.

Nicholson MS, Arzeni CB (1993) The market medicinal plants of Monterrey, Nuevo León México. Economic Botany 47: 184-92.

Parente CET, da Rosa MMT (2001) Plantas comercializadas como medicinais no Município de Barra do Piraí, RJ. Rodriguésia 52: 47-59.

Patiri B, Borah A (2007) Wild Edible Plants of Assam. Guwahati, India: Geetakhi Printers and Publishers.

Rabha D (2014) Above ground biomass and carbon stocks of an undisturbed regenerating sal (Shorea robusta Gaertn. F.) forest of Goalpara district, Assam, Northeast India. International Journal of Environment 3: 147-155.

Rabha PK (2012) Forest Resource Entrepreneurship: Case study of Goalpara District of Assam. International Journal of Computer Applications in Engineering Sciences, Special Issue on Basic, Applied \& Social Sciences 2: 361-363.

Santos EB, Dantas GS, Santos HB, Diniz MFFM, Sampaio FC (2009) Ethno-botanical studies of medicinal plants for oral conditions in the municipality of Joao Pessoa, Brazil. Revista Brasileira de Farmacognosia 19: 321-324.

Silalahi M, Walujo EB, Supriatna J, Mangunwardoyo W (2015) The local knowledge of medicinal plants trader and diversity of medicinal plants in the Kabanjahe traditional market, North Sumatra, Indonesia. Journal of Ethnopharmacology 175: 432-43.

Silva MS, Peixoto Al (2009) Abajuru (Chrysobalanus icaco L. and Eugenia rotundifolia Casar.) commercialized in Rio de Janeiro, Brazil. Revista Brasileira de Farmacognosia. 19: 325-332.

Tibuhwa DD (2018) Edible and Medicinal Mushrooms Sold at Traditional Markets in Tanzania. Research. Journal of Forestry 12: 1-14. 
Tinitana F, Rios M, Romero-Benavides JC, de la Cruz Rot M. Pardo-de-Santayana M (2016) Medicinal plants sold at traditional markets in southern Ecuador. Journal of Ethnobiology and Ethnomedicine 12:1-18.

Vlkova M, Verner V, Kandakov A, Polesny Z, Karabaev N, Pawera L, Nadvornikowa I, Banout J (2015) Edible plants sold on marginal rural markets in Fergana Valley, southern Kyrgyzstan. Bulgarian Journal of Agricultural Sciences 21: 243-250.

Williams VL, Balkwill K, Witkowski ETF (2007a). Size-class prevalence of bulbous and perennial herbs sold in the
Johannesburg medicinal plant markets between 1995 and 2001 . South African Journal of Botany 73: 144-55.

Williams VL, Witkowski ETF, Balkwill K (2007b) The use of incidence-based species richness estimators, species accumulation curves and similarity measure to appraise ethnobotanical inventories from South Africa. Biodiversity Conservation 16: 2495-513.

Williams VL, Witkowski ETF, Balkwill K (2009). Volume and financial value of species traded in the medicinal plant market of Gauteng South Africa. International Journal of Sustainable Development and World Ecology 14: 584-603. 